\title{
RESTORING THE FACT/LAW DISTINCTION IN PATENT CLAIM CONSTRUCTION
}

\author{
J. Jonas Anderson ${ }^{*}$ and Peter S. Menell ${ }^{* *}$
}

\section{INTRODUCTION}

Two decades ago, the Supreme Court sought to promote more effective, transparent patent litigation in Markman $v$. Westview Instruments ${ }^{1}$ by ruling that "the construction of a patent, including terms of art within its claim, is exclusively within the province of the court."2 In so doing, the Court removed interpretation of patent claims from the black box of jury deliberations by holding that the Seventh Amendment right to a jury trial did not extend to patent claim construction. Failing to find clear historical evidence of how claim construction was handled in $1791,{ }^{3}$ the Court turned to "the relative interpretive skills of judges and juries and the statutory policies that ought to be furthered by the allocation." "It concluded that federal district court judges were better equipped than juries to resolve the mixed fact/law controversies inherent in construing disputed patent claim terms, ${ }^{5}$ thereby leading to more effective and transparent patent litigation. Fully achieving the Court's goal of more effective and transparent patent litigation, however, depends on district judges having the flexibility to learn pertinent facts, build a reviewable record, and explain the basis for their claim constructions.

Courts interpret patent claims from the perspective of persons having ordinary skill in the art as of the time of the invention. ${ }^{6}$ Since few judges

\footnotetext{
* Assistant Professor of Law, American University, Washington College of Law.

** Koret Professor of Law and Director, Berkeley Center for Law \& Technology, University of California at Berkeley School of Law.

Professor Anderson and Professor Menell, along with Professor Arti Rai, co-authored an amicus brief in Teva Pharmaceuticals USA, Inc. v. Sandoz, Inc., 135 S. Ct. 831 (2014) htrtp:/perma.cc/AU5NFZ62]. That brief drew upon J. Jonas Anderson and Peter S. Menell, Informal Deference: A Historical, Empirical, and Normative Analysis of Patent Claim Construction, 108 Nw. U. L. REV. 1 (2014) [http://perma.ce/MFA5-HXAX].

1517 U.S. 370 (1996) [https://perma.cc/2BDS-SPRY].

${ }^{2}$ Id. at 372

${ }^{3}$ Id. at 376-84 (citing Charles W. Wolfram, The Constitutional History of the Seventh Amendment, 57 MINN. L. REv. 639, 640-643 (1973) [http:/perma.cc/4BYA-324K]; Tull v. United States, 481 U.S. 412, 417 (1987) [hitps://perma.cc/87KF-HJMV]) (explaining that under the "historical test," the Court examines whether a cause of action was tried at law (or was analogous to a cause of action tried at law) at the time of the founding of the nation).

${ }^{4}$ Id. at 384 .

${ }^{5} I d$. at $388-90$

${ }^{6}$ See Multiform Desiccants, Inc. v. Medzam, Ltd., 133 F.3d 1473, 1477 (Fed. Cir. 1998)
} 
have such training and knowledge, they must step into the shoes of skilled artisans. As Professor William Callyhan Robinson explained more than a century ago, the court may look to:

[T] estimony to explain the meaning of its language, or to expert evidence to ascertain the essential characteristics of the described invention and the differences between it and other patented inventions, or to papers in the Patent Office which are connected with the patent ... to show the significance which [the inventor] attached to the terms. ${ }^{7}$

Thus, when parties dispute the skilled artisan's interpretation of patent claim meaning, resolution of the controversy appears to have a factual character.

Unfortunately, Markman's promise of more effective and transparent patent adjudication has been frustrated by the Federal Circuit's adherence to de novo review of all aspects of district judges' claim determinations, including how skilled artisans understand patent claim terms. ${ }^{8}$ This standard has had the perverse effect of dissuading district judges from holding evidentiary hearings ${ }^{9}$ or explaining the reasoning behind their claim constructions. ${ }^{10}$ The Federal Circuit's view that claim construction is a pure question of law has instead focused district judges' attention on reading and

[https://perma.cc/RAZ8-WRJT]

73 WILLIAM C. ROBINSON, THE LAW OF PATENTS FOR USEFUL INVENTIONS 248 (1890).

${ }^{8}$ See, e.g., Lighting Ballast Control LLC v. Philips Elecs. N. Am. Corp., 744 F.3d 1272 (Fed. Cir 2014) (en banc), vac'd and remanded sub nom. Lighting Ballast Control LLC v. Universal Lighting Techs., Inc., 135 S. Ct. 1173 (2015) (mem.) [https://perma.cc/K84J-FNVP]; Cybor Corp. v. FAS Techs., Inc., 138 F.3d 1448 (Fed. Cir. 1998) (en banc) [https://perma.cc/X2QH-T4DD].

${ }^{9}$ Commenting on the high reversal rate for claim construction, one district court judge has observed that "you might as well throw darts." See Anandashankar Mazumdar, Federal District Courts Need Experts that Are Good 'Teachers, 'Judges Tell Bar, 70 PAT. TRAdEMARK \& CoPyright J. (BNA) 536, 537 (Sept. 16, 2005) (quoting Judge Marsha J. Pechman of the U.S. District Court for the Western District of Washington). See generally J. Jonas Anderson and Peter S. Menell, Informal Deference: $A$ Historical, Empirical, and Normative Analysis of Patent Claim Construction, 108 NW. U. L. REV. 1, 5 (2014) [hereinafter Informal Deference] [http:/perma.cc/MFA5-HXAX].

10 See, e.g., Hollingsworth \& Vose Filtration Ltd. v. Delstar Techs., Inc., No. 10-788 GMS (D. Del. Jul. 10, 2012), available at http:// www.scribd.com/doc/100456939/Hollingsworth-Vose-Filtration-Ltd$v$-Delstar-Techs-Inc-C-A-No-10-788-GMS-D-Del-Jul-10-2012 (Order Construing the Terms of U.S. Pat. No. $6,623,548$ ) (cursory opinion with no discussion of factual predicates, evidentiary sources, or explication of the claim construction process; footnotes limited to discussion of intrinsic sources and Federal Circuit jurisprudence) [http:/perma.cc/9EAA-EJZQ]; Shelbyzyme LLC v. Genzyme Corp., No. 09-768 GMS (D. Del. Jul. 8, 2011), available at http://www.delawareiplaw.com/2011/07/chief judge sleet_claim_constr.html (Order Construing the Terms of U.S. Pat. No. 7,011,831) (cursory opinion with a footnote summarizing Federal Circuit precedent emphasizing the primacy of intrinsic evidence and noting that "the parties presented conflicting extrinsic evidence ... which the court will not consider") [http:/perma.cc/HQ97-9QEB]; In re Rembrandt Techs., LP Patent Litig., No. 07-md-1848 GMS, 2008 WL 5773604 (D. Del. Nov. 19, 2008) (construing over 100 claim terms without setting forth any analysis in the claim construction order). 
rereading the patent specification without the opportunity to fully and directly engage with those most familiar and conversant with patent claim language in its technological, industrial, and claim-drafting context. For district judges to even intimate that they were making factual findings invited reversal. ${ }^{11}$

The Supreme Court returned to the issue of patent claim construction during its current Term. Overturning two decades of Federal Circuit practice, the Court's much anticipated decision in Teva Pharmaceuticals USA, Inc. v. Sandoz, Inc. ${ }^{12}$ clearly established that patent claim construction can entail fact-finding and restored the fundamental juridical principlereflected in Federal Rule of Civil Procedure 52(a)(6) - that the Federal Circuit, like other appellate courts, must "give due regard to the trial court's opportunity to judge the witnesses' credibility" and defer to the trial court's factual determinations unless "clearly erroneous."13

Part I of this Article traces the background of the de novo review controversy. Part II summarizes the Supreme Court's Teva decision, analyzes the Court's logic, and then explores the case's ramifications for patent case management in Part III. Finally, Part IV examines the interplay between patent claim construction and claim indefiniteness, a related patent doctrine that has recently attracted Supreme Court attention. ${ }^{14}$

\section{THE RoOTS OF THE CONTROVERSY SURROUNDING DE Novo REVIEW OF PATENT CLAIM CONSTRUCTION}

The controversy in the Teva decision can be traced back to the rise of patent jury trials in the 1970s and 1980s. For much of patent law's history, patent litigators have preferred bench trials. Various factors - such as speedier decisions, jurors' willingness to accord greater significance to a patent's presumption of validity, dispensing with post-trial briefs and proposed findings, the greater emphasis on excluding inadmissible evidence, and possibly appellate courts' reluctance to disturb jury decisions ${ }^{15}$ - led to a steep rise in the use of juries in patent cases. Juries were used in less than $10 \%$ of patent cases prior to 1970 , but by the early $1990 \mathrm{~s}$, that number rose to over 70\%. ${ }^{16}$ The newly formed Federal Circuit, established in 1982, saw this as an impediment to reviewing patent

\footnotetext{
11 See Cybor, 138 F.3d at 1475 (Rader, J., dissenting in part, concurring in the judgment, and joining Part IV of the en banc opinion) (suggesting that the de novo standard encourages trial judges to "disguise the real reasons for their interpretation").

12135 S. Ct. 831 (2015) [http//perma.co/AU5N-FZ62].

13 FED. R. CIV. P. 52(a)(6); see also Teva, 135 S. Ct. at 834.

14 See Nautilus, Inc. v. Biosig Instruments, Inc., 134 S. Ct. 2120 (2014) [https:/perma.cc/U8JQ$4 \mathrm{KP} 4 \mathrm{]}$.

${ }^{15}$ Gary M. Ropski, Constitutional and Procedural Aspects of the Use of Juries in Patent Litigation (Part I), 58 J. PAT. OfF. SOC'Y 609, 612-13 (1976).

${ }^{16}$ Informal Deference, supra note 9, at 18-21.
} 
decisions consistently. ${ }^{17}$ The critical issue of claim construction was shrouded in the mystery of jury deliberations.

\section{A. The Markman Decision: Trial Judges and Claim Construction}

The Federal Circuit considered this impediment to transparency in its en banc Markman decision. ${ }^{18}$ Some Federal Circuit judges assumed that if claim construction involved factual issues, then the Seventh Amendment right to a jury trial prevented a district judge from construing the patent claim. ${ }^{19}$ The majority opinion, however, worked around the Seventh Amendment impediment by holding that the construction of a patent claim is a pure question of law, ${ }^{20}$ which had the effect of allocating responsibility to construe patents to the district judge. It also meant that the district judge's construction of the claim was subject to de novo review. ${ }^{21}$ The court masked the inherently factual nature of claim construction by reasoning that although the trial judge may use both intrinsic and extrinsic evidence in construing claims:

$[E] n$ route to pronouncing the meaning of claim language as a matter of law based on the patent documents themselves, the court is not crediting certain evidence over other evidence or making factual evidentiary findings. Rather, the court is looking to the extrinsic evidence to assist in its construction of the written document, a task it is required to perform. ${ }^{22}$

The Supreme Court affirmed the Federal Circuit's conclusion that the Seventh Amendment did not require claim construction to be allocated to juries, but through very different reasoning. ${ }^{23}$ The Court held that the district judge should be responsible for claim construction based on judges' "training in exegesis [of written instruments]," ${ }^{24}$ notwithstanding what it characterized as the "mongrel [or mixed fact/law] practice" of patent claim construction. ${ }^{25}$ In a critical passage, the Court explained:

[C]redibility judgments have to be made about the experts who testify in patent cases, and in theory there could be a case in which a simple credibility judgment would suffice to choose between experts whose testimony was

\footnotetext{
17 See Paul R. Michel, The Challenge Ahead: Increasing Predictability in Federal Circuit Jurisprudence for the New Century, 43 AM. U. L. REv. 1231, 1238-39 (1994) [http:/perma.co/LU45HBA5].

${ }^{18}$ Markman v. Westview Instruments, Inc., 52 F.3d 967 (Fed. Cir. 1995) (en banc) [hitps://perma.cc/8CEU-GEZ7].

19 See id. at 992-98 (Mayer, J., concurring); 1010-17 (Newman, J., dissenting). But see id. at 98387 (majority opinion).

${ }^{20}$ Id. at $978-79$.

${ }^{21}$ Id. at 979 .

${ }^{22} \mathrm{Id}$. at 981 (italics in original) (footnote omitted).

${ }^{23}$ Markman v. Westview Instruments, Inc., 517 U.S. 370 (1996).

${ }^{24} I d$. at 388.

25 Id. at 378 .
} 
equally consistent with a patent's internal logic. But our own experience with document construction leaves us doubtful that trial courts will run into many cases like that. In the main, we expect, any credibility determinations will be subsumed within the necessarily sophisticated analysis of the whole document, required by the standard construction rule that a term can be defined only in a way that comports with the instrument as a whole. Thus, in these cases a jury's capabilities to evaluate demeanor, to sense the "mainsprings of human conduct," or to reflect community standards, are much less significant than a trained ability to evaluate the testimony in relation to the overall structure of the patent. The decisionmaker vested with the task of construing the patent is in the better position to ascertain whether an expert's proposed definition fully comports with the specification and claims and so will preserve the patent's internal coherence. We accordingly think there is sufficient reason to treat construction of terms of art like many other responsibilities that we cede to a judge in the normal course of trial, notwithstanding its evidentiary underpinnings. ${ }^{26}$

In contrast to the Federal Circuit's Markman opinion, the Supreme Court did not deem patent claim construction purely a question of law. Rather, consistent with its characterization of claim construction as a "mongrel practice," the Court noted merely that claim construction was a matter "exclusively within the province of the court."27

Barely two weeks after the Supreme Court's Markman ruling, a Federal Circuit panel in another case heavily discounted the use of extrinsic evidence, warning that "[a]llowing the public record to be altered or changed by extrinsic evidence introduced at trial, such as expert testimony, would make this right meaningless. ${ }^{928}$ By contrast, other Federal Circuit opinions viewed claim construction as a mixed question of law and fact for which fact-finding could be set aside only upon a showing of clear error. ${ }^{29}$

\section{B. The Cybor and Phillips Decisions: Adhering to De Novo Review}

This split precipitated the Federal Circuit's en banc review of the appellate claim construction standard in Cybor Corp. v. FAS Technologies, Inc. ${ }^{30}$ In a sharply divided decision, a majority of the Federal Circuit reaffirmed its view that claim construction is a pure question of law subject to de novo review and downplayed the Supreme Court's more limited characterization of claim construction as simply an "issue for the judge, not

\footnotetext{
${ }^{26} I d$. at $389-90$ (citations omitted).

27 Id. at 372 .

28 Vitronics Corp. v. Conceptronic, Inc., 90 F.3d 1576, 1583 (Fed. Cir. 1996) [http://perma.cc/FQQ2-K65H].

${ }^{29}$ See, e.g., Wiener v. NEC Elecs., Inc., 102 F.3d 534, 539 (Fed. Cir. 1996) [https:/perma.cc/R7VB-852H]; Metaullics Sys. Co. v. Cooper, 100 F.3d 938, 939 (Fed. Cir. 1996) [hitps://perma.cc/7MHZ-67NA].

30138 F.3d 1448 (Fed. Cir. 1998) (en banc).
} 
the jury." 31 In the majority's view, "[n]othing in the Supreme Court's opinion supports the view that the Court endorsed a silent, third optionthat claim construction may involve subsidiary or underlying questions of fact." ${ }^{32}$ The majority discounted the Supreme Court's characterization of claim construction as a "mongrel practice ... fall[ing] somewhere between a pristine legal standard and a simple historical fact" as merely "prefatory comments. ${ }^{.33}$ It also overlooked the Supreme Court's statement that "there is sufficient reason to treat construction of terms of art like many other responsibilities that we cede to a judge in the normal course of trial, notwithstanding its evidentiary underpinnings." ${ }^{\text {"34 }}$ Yet "[c]ourts commonly recite the deferential 'abuse of discretion' test as broadly and generally appropriate on review of evidence calls. ${ }^{.35}$

While properly emphasizing the primacy of intrinsic evidence to claim construction, the Vitronics and Cybor line of cases steered district judges away from learning from skilled artisans and using evidentiary techniques for resolving disputes among proffered experts. Following the Cybor decision, the unusually high reversal rate for claim construction rulings ${ }^{36}$ reached $44.2 \%$ on a per claim term basis in $2004,{ }^{37}$ signaling dissensus. ${ }^{38}$

In an effort to address the inconsistency across its own decisions and quell the widespread dissatisfaction among district judges and practitioners with its claim construction jurisprudence, the Federal Circuit granted en banc review of a wide range of claim construction questions in Phillips $v$. $A W H$ Corp. ${ }^{39}$ Although the en banc order inviting briefs listed the standard

31 Compare id. at 1455,1456 (concluding that "the standard of review in [the Federal Circuit's Markman decision]... was not changed by the Supreme Court's decision..., and we therefore reaffirm that, as a purely legal question, we review claim construction de novo on appeal including any allegedly fact-based questions relating to claim construction") with Markman, 517 U.S. at 391.

32 Cybor, 138 F.3d at 1455 . It is difficult to see how the Supreme Court's characterization of claim construction as a "mongrel practice" did not support the third option.

33 Id. (quoting Markman, 517 U.S. at 378, 388).

34 Markman, 517 U.S. at 390.

35 Steven Alan Childress, Standards of Review Primer: Federal Civil Appeals, 229 F.R.D. 267, 289 (2005).

36 See Kimberly A. Moore, Markman Eight Years Later: Is Claim Construction More Predictable?, 9 LEWIS \& CLARK L. REV. 231, 232-34 (2005) [http:/perma.cc/9AKZ-RSF7].

37 Informal Deference, supra note 9, at 40-41.

38 The panel decision in Texas Digital Systems, Inc. v. Telegenix, Inc., 308 F.3d 1193 (Fed. Cir. 2002) [https:/perma.cc/6ADH-C6V3] sought to further clarify the claim construction framework by recognizing dictionaries, encyclopedias, and treatises as "particularly useful resources to assist the court in determining the ordinary and customary meanings of claim terms" due to their public availability and objectivity. Id. at 1202. The court noted that, unlike expert testimony, these reference sources are not "colored by the motives of the parties" or "inspired by litigation." Id. at 1203. "Indeed, these materials may be the most meaningful sources of information to aid judges in better understanding both the technology and the terminology used by those skilled in the art to describe the technology." $I d$. Yet the reversal rate continued to rise after the Texas Digital decision. See Informal Deference, supra note 9, at 41.

39376 F.3d 1382 (per curiam) [https://perma.cc/FNB8-8PM4]. 
of appellate review among the seven questions presented ${ }^{40}$ the majority opinion ultimately sidestepped the issue. Nonetheless, the Federal Circuit appeared to backtrack from Vitronics skepticism of the use of extrinsic evidence. The majority in Phillips authorized district judges to consider extrinsic evidence, but deemed such evidence to be less significant and reliable in determining the scope of claim terms. ${ }^{41}$ The majority recognized that expert testimony can be useful:

[T]o provide background on the technology at issue, to explain how an invention works, to ensure that the court's understanding of the technical aspects of the patent is consistent with that of a person of skill in the art, or to establish that a particular term in the patent or the prior art has a particular meaning in the pertinent field. However, conclusory, unsupported assertions by experts as to the definition of a claim term are not useful to a court. ${ }^{42}$

While the ultimate Phillips decision formally retained the de novo standard, the reversal rate dropped precipitously the week that the Phillips argument was heard and has remained approximately one-third below the pre-Phillips reversal rate. ${ }^{43}$ Even though a majority of Federal Circuit judges were unwilling to reverse the Cybor de novo standard, our analysis reveals that by mid-2005 a consensus emerged among members of the court that the court should ratchet back appellate scrutiny of claim construction determinations. ${ }^{44}$ The indications supporting this inference include: (1) the reversal rate dropped well before any district court cases that could have been influenced by the Phillips decision reached the Federal Circuit, ${ }^{45}$ (2) the rate dropped for all members of the Federal Circuit, ${ }^{46}$ (3) the rate fell across all technology fields except one (business methods - which could be explained by the hand-wringing over patent eligibility that ultimately led to the Bilski $i^{47}$ and Alice ${ }^{48}$ decisions), ${ }^{49}$ and (4) the rate of summary affirmances substantially increased following Phillips. ${ }^{50}$

\footnotetext{
${ }^{40}$ Id. at 1383 .

41 Phillips v. AWH Corp., 415 F.3d 1303, 1317-18 (Fed. Cir. 2005) (en banc) [https://perma.cc/6A6L-EH87].

${ }^{42}$ Id. at 1318 (citations omitted).

43 Informal Deference, supra note 9, at 61 fig. 10.

44 See id. at 56-62.

45 See id. at 61 .

46 See id. at $49-51$.

${ }^{47}$ In re Bilski, 545 F.3d 943 (Fed. Cir. 2008) (en banc) [https://perma.cc/2ZQU-UKNQ], aff'd on other grounds sub nom. Bilski v. Kappos, 561 U.S. 593 (2010) [https://perma.cc/LW6Z-VE7A].

${ }^{48}$ CLS Bank Int'l v. Alice Corp., 717 F.3d 1269 (Fed. Cir. 2013) (en banc) [https:/perma.cc/6DUPJHNM], aff'd on other grounds, $134 \mathrm{~S}$. Ct. 2347 (2014) [htips://perma.cc/QC8B-587A].

${ }^{49}$ See Informal Deference, supra note 9 , at 51-54.

50 See id. at $54-55$.
} 


\section{The Road to Teva}

The division among Federal Circuit judges over the standard of appellate review continued to resurface over the past decade ${ }^{51}$ Patent claim construction arises in many patent appeals, which forced members of the court to confront their differing approaches. In addition, the 2010 appointment of Judge Kathleen O'Malley brought a trial judge's perspective to the Federal Circuit for the first time in the appellate tribunal's history. ${ }^{52}$

In 2013, the Federal Circuit granted en banc review of the standard of appellate review of claim construction rulings in Lighting Ballast Control LLC v. Philips Electronics North America Corp ${ }^{53}$ Many thought the court would finally rectify the split over appellate review of claim construction. In a surprising opinion-in which several Federal Circuit judges who had previously questioned the Cybor de novo standard now voted to perpetuate its application-a majority of the court upheld the standard on stare decisis grounds. ${ }^{54}$ In a vigorous dissent, Judge O'Malley, joined by Chief Judge Rader and Judges Reyna and Wallach, castigated the majority for "misapprehend[ing] the Supreme Court's guidance, contraven[ing] the Federal Rules of Civil Procedure, and add[ing] considerable uncertainty and expense to patent litigation." ${ }^{35}$ While the petition for certiorari in Lighting Ballast was pending, the Supreme Court granted review of the standard of appellate review of claim construction rulings in Teva Pharmaceuticals USA, Inc. v. Sandoz, Inc.

\section{TeVA PhaRMaCEUTICALS USA, INC. V. SANDOZ: RESTORING THE PROPER APPELLATE ROLE}

Teva Pharmaceuticals, the owner of a patent covering the manufacturing method for Copaxone, a multiple sclerosis drug, filed suit

\footnotetext{
51 See, e.g., Retractable Techs., Inc. v. Becton, Dickinson \& Co., 659 F.3d 1369, 1373 (Fed. Cir. 2011) (O'Malley, J., dissenting from denial of rehearing en banc) [https://perma.cc/BE5V-QWQD], cert. denied, 133 S. Ct. 833 (2013) (mem.) [https:/perma.cc/TMK6-K 7E4]; Trading Techs. Int'l, Inc. v. eSpeed, Inc., 595 F.3d 1340, 1350-51 (Fed. Cir. 2010) [https://perma.cc/L4HN-UKU3]; id. at 1363-64 (Clark, District Judge (E.D. Tex.), concurring); Medegen MMS, Inc. v. ICU Med., Inc., 317 F. App'x 982, 988-91 (Fed. Cir. 2008) (Walker, Chief District Judge (N.D. Cal.), dissenting) (urging greater deference) [http://perma.cc/79MW-BBZ2]; Amgen Inc. v. Hoechst Marion Roussel, Inc., 469 F.3d 1039, 1040 (Fed. Cir. 2006) (Michel, C.J., joined by Rader, J., dissenting from denial of rehearing en banc) [https://perma.cc/7EGV-7XXE].

52 See David Ingram and Mike Scarcella, White House Rolls Out Two More Circuit Nominees, THE BLT: THE BLOG OF LEGAL TIMES (Mar. 10, 2010), http://legaltimes.typepad.com/blt/2010/03/whitehouse-rolls-out-two-more-circuit-nominees.html [http://perma.cc/2QFV-GKAU]

53500 F. App'x 951 (Fed. Cir. 2013) (per curiam).

54 Lighting Ballast Control LLC v. Philips Elecs. N. Am. Corp., 744 F.3d 1272, 1276-77 (Fed. Cir. 2014) (en banc), vac'd and remanded sub nom. Lighting Ballast Control LLC v. Universal Lighting Techs., Inc., 135 S. Ct. 1173 (2015) (mem.).

${ }^{55}$ Id. at 1297 (O'Malley, J., dissenting).
} 
against Sandoz and several other firms seeking to market generic versions of the drug. Sandoz defended on the grounds that the patent was invalid because Copaxone's active ingredient, characterized as having "a molecular weight of 5 to 9 kilodaltons," was indefinite. ${ }^{56}$ The patent did not specify how molecular weight was determined and hence was "not amenable to construction or ... insolubly ambiguous," ${ }^{57}$ the Federal Circuit's indefiniteness standard at the time. ${ }^{58}$

Sandoz contended that there were three methods to determine this weight - the weight of the most prevalent molecule, the weight as calculated by the average weight of all molecules, or weight as calculated by an average in which heavier molecules count for more-and therefore Teva's failure to specify a precise meaning rendered the claim insolubly ambiguous. ${ }^{59}$ After considering conflicting expert evidence, the district judge credited the testimony of Teva's expert in concluding that "a skilled artisan would understand that the term "molecular weight" is the weight of the most prevalent molecule. ${ }^{60}$ On appeal, the Federal Circuit reviewed the district judge's claim construction de novo and concluded that the claim term in question was insolubly ambiguous. ${ }^{61}$

The Supreme Court then granted certiorari on the issue of the standard of appellate review in patent claim construction. ${ }^{62}$ Justice Breyer's majority opinion began with reference to the Court's 1996 Markman decision, noting that the Teva case "involve[d] claim construction with "evidentiary underpinnings, ${ }^{\prime \prime 63}$ an issue that the Federal Circuit downplayed in its adherence to the Circuit's own framework. Justice Breyer then crisply set forth the operative principle governing appellate review, holding that Federal Rule of Civil Procedure 52(a)(6) requires a court of appeals to uphold a district court's findings of fact unless they are clearly erroneous. ${ }^{64}$ The opinion then emphasized that this "clear command" applies to all of the courts of appeals and "does not make exceptions or purport to exclude

\footnotetext{
56 Teva Pharms. USA, Inc. v. Sandoz, Inc., 135 S. Ct. 831,842 (2015). 35 U.S.C. $\$ 112$ (b) (2012) requires that "[t]he specification shall conclude with one or more claims particularly pointing out and distinctly claiming the subject matter which the inventor or a joint inventor regards as the invention" (emphasis added) [hitp://permacc/4A63-6MCH].

57 See Power-One, Inc. v. Artesyn Techs., Inc., 599 F.3d 1343, 1350 (Fed. Cir. 2010) (quoting Datamize LLC v. Plumtree Software, Inc., 417 F.3d 1342, 1347 (Fed. Cir. 2005) [https:/perma.cc/94YK-MFK2]) [https:/perma.cc/7LLG-20ZC].

58 The Supreme Court broadened the indefiniteness standard after the lower court determinations in Teva. See generally Nautilus, Inc. v. Biosig Instruments, Inc., 134 S. Ct. 2120 (2014).

${ }^{59}$ Teva, $135 \mathrm{~S}$. Ct. at 836.

${ }^{60} \mathrm{Id}$.

61 See Teva Pharms. USA, Inc. v. Sandoz, Inc., 723 F.3d 1363, 1369 (Fed. Cir. 2013) [https:/perma.cc/YP76-VCYT].

${ }^{62}$ Teva, 135 S.Ct. at 836 .

${ }^{63} \mathrm{Id}$. at 835.

${ }^{64} \mathrm{Id}$.
} 
certain categories of factual findings[, including] both subsidiary and ultimate facts [and to findings made by a] district court sitting without a jury."."65

The Court noted that its Markman decision "neither created, nor argued for, an exception to Rule 52(a)," factfinding is sometimes necessary" in patent claim construction, ${ }^{67}$ directly contradicting nearly two decades of Federal Circuit jurisprudence. The majority recognized that while "[c]onstruction of written instruments often presents a 'question solely of law,' at least when the words in those instruments are "used in their ordinary meaning," extrinsic evidence may help when "a written instrument uses "technical words or phrases not commonly understood." "And in that circumstance, the "determination of the matter of fact' will 'preced[e]' the 'function of construction.' ... This factual determination, like all other factual determinations, must be reviewed for clear error."

The Supreme Court noted that clear error review is "particularly" important" in patent cases because "so much depends upon familiarity with specific scientific problems and principles not usually contained in the general storehouse of knowledge and experience." ${ }^{70}$ The Court further emphasized that "[a] district court judge who has presided over, and listened to, the entirety of a proceeding has a comparatively greater opportunity to gain that familiarity than an appeals court judge who must read a written transcript or perhaps just those portions to which the parties have referred."'11

Building on its Markman framework, the Supreme Court's Teva decision endorses a hybrid standard of appellate review that is balanced, structurally sound, and legally appropriate. Under this hybrid standard,

\footnotetext{
${ }^{65}$ Id. at 836-37 (quoting Anderson v. Bessemer City, 470 U.S. 564, 573-74 (1985) [https:/perma.cc/N2MQ-TGUJ]; Pullman-Standard v. Swint, 456 U.S. 273, 287 (1982) [https://perma.cc/8PPA-YJLP]) (internal quotation marks omitted).

${ }^{66} \mathrm{Id}$. at 837 .

${ }^{67}$ Id. at 838 . The Court noted that its Markman decision "referred to claim construction as a practice with 'evidentiary underpinnings,' a practice that 'falls somewhere between a pristine legal standard and a simple historical fact"" and "sometimes" required courts to make "credibility judgments" about witnesses." Id. (quoting Markman v. Westview Instruments, Inc., 517 U.S. 370, 378, 388, 389-90 (1996)).

${ }^{68}$ Id. at 837 .

69 Id. (quoting Great N. Ry. Co. v. Merchants Elevator Co., 259 U.S. 285, 291-92 (1922) [http://perma.cc/GT7M-EMEV]) (alternation in original) (internal citations omitted).

${ }^{70}$ Id. at 838 (quoting Graver Tank \& Mfg. Co. v. Linde Air Products Co., 339 U.S. 605, 610 (1950) [http:/perma.cc/99RA-GWAN]) (internal quotations omitted).

${ }^{71}$ Id. Justice Breyer referenced Judge O'Malley's dissent in Lighting Ballast contending that "Federal Circuit judges 'lack the tools that district courts have available to resolve factual disputes fairly and accurately,' such as questioning the experts, examining the invention in operation, or appointing a court-appointed expert." Id. at 838-39 (quoting Lighting Ballast Control LLC v. Philips Elecs. N. Am. Corp., 744 F.3d 1272, 1311 (Fed. Cir. 2014) (en banc) (O’Malley, J., dissenting)).
} 
factual determinations underlying claim construction rulings are subject to the "clearly erroneous" (or "abuse of discretion") standard of review, while the Federal Circuit exercises de novo review over the ultimate claim construction decision. In this manner, district judges can use their distinctive vantage point and evidentiary tools to ferret out factual underpinnings while the Federal Circuit can operate as a check on fidelity to the patent instrument. Therefore, even though the Federal Circuit retains de novo review of whether a trial court's construction of a patent claim comports with the intrinsic evidence-the patent document and prosecution history - the appellate court must nonetheless sustain the trial court's subsidiary factual findings unless clearly erroneous. Thus, where the intrinsic evidence does not resolve the meaning of a disputed patent claim term, the district court's resolution, if adequately grounded in extrinsic evidence, will control. ${ }^{72}$

\section{Implementing the TEVA Regime: Patent CaSe Management}

In order to realize the promise of effectiveness and transparency that the Supreme Court sought in its Markman decision and garner the deference contemplated by Rule 52(a) as stressed in Teva, district judges should (1) delineate the disputed subsidiary factual questions prior to the Markman proceeding, (2) conduct focused briefing with supporting expert declarations and evidentiary hearings to create an adequate record for resolving such disputes, and (3) prepare a careful Markman order explaining the basis for their claim construction.

This process can be standardized through augmentation of the Patent Local Rules used in many jurisdictions. ${ }^{73}$ Such rules provide for the exchange of proposed terms for construction by specified dates. Thereafter, the parties must meet and confer to narrow or resolve differences. If they cannot resolve their differences, they must prepare a joint claim construction and prehearing statement. ${ }^{74}$ Within three weeks of the joint statement, the parties must simultaneously exchange proposed constructions of each disputed claim term and references from the patent specification or prosecution history that support its proposed construction and designate any supporting extrinsic evidence. ${ }^{75}$

The Teva decision can be implemented most effectively by requiring parties to specifically identify underlying disputed facts in connection with

\footnotetext{
${ }^{72}$ Justice Thomas, joined by Justice Alito, dissented on the ground that claim construction does not involve fact-finding. Id. at 845 (Thomas, J., dissenting). The dissent analogized claim construction to statutory construction. $I d$.

73 See generally Peter S. Menell, et AL., PATENT CASE MANAGEMEnt Judiclal Guide ch. 5 (Federal Judicial Center, 2d ed. 2012), available at http:/papers.ssrn.com/sol3/papers.cfm? abstract_id=2114398 [http:/perma.cc/P7VX-4FWC].

74 See, e.g., N.D. CAL. PATENT L.R. 4-1 [http://perma.ce/JU34-CGED].

75 See id. at $4-2$.
} 
disputed claim terms and how those disputed facts relate to the intrinsic evidence in the joint claim construction statement. The parties should also designate their proposed means of resolving the factual disputes. The district judge would then be in a position to structure the Markman hearing so as to develop a proper record for making factual findings. For example, the judge could request that the parties present expert testimony, with crossexamination. Following the hearing, the judge would then prepare an order explaining her view of the intrinsic evidence and any subsidiary factual findings. The Federal Circuit would then have a clear record of the basis for the judge's claim construction as well as the judge's reasoning.

There is some risk that the Teva decision will result in greater cost and delay as parties engage in escalating battles of the experts. Such problems, however, are not unique to patent adjudication, although the technological complexity of patent cases creates greater opportunity for such tactics. District judges must be vigilant in emphasizing the centrality of the intrinsic evidence and exercise due caution in entertaining extrinsic evidence. After all, the Federal Circuit will scrutinize the district judge's decision to go beyond the intrinsic evidence to interpret claim meaning.

It is important to recognize that although many terms in patent claims are beyond a district judge's general experience, scientists and engineers have relatively clear understandings within their fields. In fact, many of the disputed terms that are appealed to the Federal Circuit are not technical scientific terms but common terms that are disputed within the context of the particular patent claim. ${ }^{76}$ Scientists or engineers who take unjustified positions risk having federal judges impugn their credibility. Since their testimony would not occur before a jury, district judges have substantial leeway to press the experts to clarify their positions. Over time, this possibility should have the desired effect of bringing parties closer together in their allegations.

The Teva decision places a greater onus on district judges to understand and explain how they parse claim language. The decision affords them greater flexibility to use familiar tools for resolving factual disputes - presentation of evidence and expert testimony. At the same time, it demands that they delineate how disputed subsidiary facts relate to the intrinsic evidence. Ultimately, this framework adds to the reliability of the dispute resolution process by bringing better evidence, more careful scrutiny, and fuller explication to bear on claim construction.

By carefully preparing for Markman hearings, selectively using focused expert testimony to resolve disputed subsidiary facts, and clearly explaining their reasoning, district judges have the ability to achieve the goal of effective, transparent, and well-reasoned patent claim constructions. As this process takes root, patent litigation will become more predictable and understandable. We can also hope that more cases will settle sooner,

${ }^{76}$ See Informal Deference, supra note 9, at 68. 
especially after Markman rulings.

\section{The InTERPlay of PATENT Claim CONSTRUCTION AND Claim INDEFINITENESS POST-TEVA}

The Teva decision also implicates appellate review and case management of claim indefiniteness, another salient patent law doctrine. ${ }^{77}$ As noted above, the claim construction controversy in the Teva case pertained to Sandoz's assertion of a claim indefiniteness invalidity defense. Since the district judge upheld the validity of Teva's patent ${ }^{78}$ and later resolved infringement claims at a bench trial, ${ }^{79}$ the allocation of decisionmaking authority between the judge and a jury with regard to resolving the indefiniteness question as well as the scope of appellate review of the claim indefiniteness determination did not surface. Nonetheless, Teva informs those questions.

Like the standard of review of patent claim construction, the Federal Circuit has viewed the standard of review of claim indefiniteness as a pure question of law pursuant to the now overruled Cybor decision. In Atmel Corp. v. Information Storage Devices, Inc. ${ }^{80}$ the Federal Circuit reasoned that:

"A determination of claim indefiniteness is a legal conclusion that is drawn from the court's performance of its duty as the construer of patent claims." See Personalized Media Communications, LLC v. International Trade Comm'n, 161 F.3d 696, 705 (Fed. Cir. 1998). Indefiniteness, therefore, like claim construction, is a question of law that we review de novo. See id. at 702; cf. Cybor Corp. v. FAS Techs., Inc., 138 F.3d 1448, 1456 (Fed. Cir. 1998) (en banc) (holding that claim construction is a question of law reviewed de novo). ${ }^{81}$

In view of the Supreme Court's rejection of Cybor's de novo standard of review of patent claim construction in Teva, there is good reason to believe that a district judge's determination of claim indefiniteness would also fall within the Rule 52(a)(6) framework on which the Supreme Court relied. Under the Supreme Court's Nautilus decision, Section 112(b) requires that "a patent's claims, viewed in light of the specification and prosecution history, inform those skilled in the art about the scope of the invention with reasonable certainty." ${ }^{282}$ Thus, like claim construction, the district judge may well need to hear from skilled artisans and resolve

\footnotetext{
77 See Nautilus, Inc. v. Biosig Instruments, Inc., 134 S. Ct. 2120, 2125 (2014).

78 See Teva Pharms. USA, Inc. v. Sandoz Inc., 810 F. Supp. 2d 578 (S.D.N.Y 2011) [https:/perma.co/483H-JNJT].

79 See Teva Pharms. USA, Inc. v. Sandoz, Inc., 876 F. Supp. 2d 295 (S.D.N.Y 2012) [https:/perma.co/G6WK-37SA].

${ }^{80} 198$ F.3d 1374 (Fed. Cir. 1999) [https://perma.ce/K3R3-8HVR].

81 Id. at 1378.

82 Nautilus, 134 S. Ct. at 2129.
} 
disputes in determining whether the claims are indefinite. And where experts disagree, the court will be required to make subsidiary factual findings based upon the credibility of the witnesses or tools available to district judges. Hence, the lower court's factual findings are entitled to deference by the Federal Circuit to the extent that the intrinsic evidence does not control.

The Teva case also sheds light on the allocation of decisionmaking authority between judge and jury. The majority confirmed that the Supreme Court used the phrase "within the province of the court" in Markman to create a distinct category of rulings with a factual basis that lie outside of the Seventh Amendment right to a jury. ${ }^{83}$ Like claim construction, the assessment of claim indefiniteness has no direct antecedent in pre-1791 cases ${ }^{84}$ Moreover, the same functional considerations that led the Court to place claim construction within the province of the court apply to indefiniteness. ${ }^{85}$ Therefore, although claim indefiniteness ought not be characterized as a pure question of law, it nonetheless falls exclusively "within the province of the court."

Even though the question of claim indefiniteness is, like claim construction, a question for the judge and not a jury, the evidentiary standard for invalidity defenses is higher (clear and convincing evidence) than for claim construction (preponderance of the evidence) due to the Patent Act's presumption of validity. ${ }^{86}$ Nonetheless, it is difficult to imagine a scenario in which a judge were to decide that a term cannot be construed under the preponderance standard but declines to hold that it is indefinite due to the higher clear and convincing standard. This seems to be a distinction without a difference, but it would nonetheless be prudent for a district judge to state in finding a claim is indefinite that she does so by clear and convincing evidence. In essence, the preponderance and clear and convincing evidence standards collapse in this situation.

The upshot of these considerations is that district judges ought to resolve the question of claim indefiniteness at the same stage that it considers claim construction. This will economize judicial resources, simplify patent litigation, and potentially increase settlement where subsidiary factual underpinnings entitle the district judge's resolution to deference on appeal.

\section{CONCLUSION}

The Supreme Court's Teva decision brings the standard of review of patent construction rulings into line with foundational juridical principles of

\footnotetext{
${ }^{83}$ Teva Pharms. USA, Inc. v. Sandoz, Inc., 135 S. Ct. 831, 837-38 (2015).

${ }^{84}$ Id. at 378-84.

85 See id. at $384-90$.

86 See 35 U.S.C. $\$ 282$ (2012) [http://perma.cc/NE65-RY9M]; cf. Microsoft Corp. v. i4i Ltd. P'ship, 131 S. Ct. 2238, 2244-51 (2011) [https://perma.cc/K8KH-QW66].
} 
appellate review, resolving one of the most divisive issues in patent litigation over the past two decades. Its efficacy, however, depends critically upon district judges earning deference for the right reasons. District judges will need to implement effective procedures for ferreting out subsidiary factual disputes bearing on claim construction, scour the intrinsic evidence for contraindications, develop a sufficient evidentiary record for resolving the dispute, and explain their analysis. To borrow a phrase from grade school teachers, district courts must not merely record their answer; they must "show their work." Such an approach holds the promise of ensuring that claim construction integrates careful analysis of the intrinsic evidence with reliable evidence, where needed, of how skilled artisans understand patent claim terms. 
